\title{
Moringa oleifera Meningkatkan Fungsi Memori pada Tikus Model Kurang Energi Protein
}

\section{Moringa oleifera Increase Memory Functions in Protein Energy Malnutrition Rat Model}

\author{
Oski Illiandri', Edi Widjajanto ${ }^{2}$, Karyono Mintaroem ${ }^{3}$ \\ ${ }^{1}$ Laboratorium Anatomi Fakultas Kedokteran Universitas Lambung Mangkurat Banjarmasin \\ ${ }^{2}$ Paska Sarjana Biomedik Fakultas Kedokteran Universitas Brawijaya Malang \\ ${ }^{3}$ Laboratorium Patologi Anatomi Fakultas Kedokteran Universitas Brawijaya Malang
}

\begin{abstract}
ABSTRAK
Malnutrisi mempunyai pengaruh negatif terhadap pertumbuhan dan perkembangan janin, khususnya pertumbuhan otak. Gangguan pertumbuhan otak serta perkembangannya dapat menyebabkan disfungsi pada penyimpanan informasi dan proses recalling, sehingga konsekuensinya akan terjadi gangguan memori. Kerusakan oksidatif merupakan salah satu jalur penyebab yang baru dikemukakan sebagai hipotesis penyebab kerusakan otak akibat malnutrisi pada tikus. Asupan nutrisi yang rendah dapat menurunkan kadar antioksidan pada tikus otak, kemudian akan menyebabkan gangguan memori yang progresif. Moringa oleifera merupakan sebuah tanaman yang populer akhir-akhir ini untuk digunakan sebagai tambahan makanan yang mengandung antioksidan di beberapa negara miskin. Tujuan dari penelitian ini adalah untuk membuktikan pengaruh bubuk ekstrak Moringa oleifera terhadap perbaikan fungsi memori pada tikus dengan kekurangan energi protein. Pada penelitian ini digunakan tikus wistar sebanyak 20 ekor, yang dibagi kedalam 5 kelompok yang terdiri dari kelompok kontrol diet malnutrisi, kelompok diet normal, kelompok diet malnutrisi yang mendapatkan tambahan diet bubuk daun Moringa oleifera dengan dosis $180 \mathrm{mg}$, kelompok diet malnutrisi yang mendapatkan tambahan diet bubuk daun Moringa oleifera dengan dosis $360 \mathrm{mg}$, dan kelompok diet malnutrisi yang mendapatkan tambahan diet bubuk daun Moringa oleifera dengan dosis $720 \mathrm{mg}$. Uji Morris watermaze digunakan untuk mengukur perbaikan memori, sedangkan metode xanthin oxidase digunakan untuk mengukur kadar antioksidan otak. Potongan hipokampus diambil sepanjang 5 s.d. $6 \mathrm{~mm}$ pada rostral sulcus cerebrocerebelaris. Penelitian ini dapat membuktikan bahwa bubuk ekstrak daun Moringa oleifera mampu meningkatkan kadar antioksidan SOD pada otak tikus dan mampu memperbaiki fungsi memori pada kekurangan energi protein.
\end{abstract}

Kata Kunci: Kelor, malnutrisi, M. Oleifera, morris watermaze test, superoxide dismutase

\begin{abstract}
Malnutrition has a negative influence on fetal growth and development including brain growth. Brain growth and development disturbance may lead dysfunction in information storage and recalling process therefore will impair memory functions, especially in malnutrition condition. Oxidative injury is an alternate pathway newly proposed which memory storage is hypothesized to be disturbed in malnutrition rat. Low intake of nutrients may lowering antioxidant level in rat brain, therefore will lead to the progression of memory impairment. Moringa oleifera is popular plant for these days which are used to enrich the daily intake in several poor country and it has proven contain several antioxidants. The aim of this study is to prove the effect of Moringa oleifera leaves powder to improve memory function in protein energy malnutrition rat. In this study subjects were 20 wistar rats divided into 5 groups consist of malnutrition diet control treatment group, normal diet treatment group, malnutrition diet treatment added with Moringa oleifera leaf powder $180 \mathrm{mg}$ dose, malnutrition diet treatment added with Moringa oleifera leaf powder $360 \mathrm{mg}$ and malnutrition diet treatment added with Moringa oleifera leaf powder $720 \mathrm{mg}$ dose. The morris watermaze was used to measure memory improvement and xanthin oxidase method was used to measure brain antioxidant level. Hipokampus section obtained at 5-6 mm rostral of sulcus cerebrocerebelaris. This research may able to prove that Moringa oleifera leaf powder increase levels of antioxidants SOD in rat brain and improve memory function in protein energy malnutrition.
\end{abstract}

Keywords: Kelor, malnutrition, M. oleifera, morris watermaze test, superoxide dismutase

Jurnal Kedokteran Brawijaya, Vol. 26, No. 1, Februari 2010; Korespondensi: Oski Illiandri. Laboratorium Anatomi Fakultas Kedokteran Universitas Lambung Mangkurat Banjarmasin, Jl. Brigjend. H. Hasan Basry Banjarmasin 70123 Tel. (0511) 3304933 Email: oski_unlam@yahoo.co.id 


\section{PENDAHULUAN}

Malnutrisi masih merupakan masalah utama di dunia. Pada tahun 1990, lebih dari 30\% balita di dunia memiliki berat badan rendah, dengan kisaran $11 \%$ di Amerika latin, 27\% di Afrika, dan 41\% di Asia. Walaupun kasus berat badan rendah telah banyak berkurang di banyak negara, akan tetapi masalah malnutrisi masih merupakan masalah utama bagi negara-negara berkembang (1). Di Indonesia sendiri malnutrisi merupakan salah satu masalah utama yang memerlukan perhatian khusus untuk segera ditangani (2). Malnutrisi yang tidak ditangani dengan baik akan mengakibatkan penyulit-penyulit yang terkadang irreversibel. Mortalitas tinggi didapatkan pada anak dengan BMI kurang dari $16 \mathrm{~kg} / \mathrm{m} 2$ (3).

Pada binatang mengerat, malnutrisi mempunyai pengaruh nyata pada perkembangan memori tikus (4). Malnutrisi mempunyai kaitan erat dengan terjadinya peroksidasi lipid pada jaringan otak (5). Secara invitro maupun invivo, otak tikus yang sedang mengalami pertumbuhan mengalami kerentanan terhadap malnutrisi. Peroksidasi lipid pada homogenate otak, dan ini menggambarkan fraksi mitokondria otak, secara signifikan lebih tinggi didapatkan pada kelompok tikus malnutrisi daripada kelompok control. Tingginya kadar MDA plasma juga didapati pada penderita malnutrisi, dan berakibat sel terutama membran sel akan mengalami kerusakan dan berakibat timbulnya penyakit-penyakit degenerasi (5). Beberapa studi menunjukkan bahwa pada otak binatang coba yang diberikan diet kurang energi protein (KEP) akan didapatkan peningkatan produk hasil oksidasi lemak berupa malondialdehyde (MDA). Bonatto menyimpulkan bahwa hal ini menunjukkan proses stres oksidatif yang terjadi akibat adanya kondisi malnutrisi pada binatang coba (6).

Penelitian yang dilakukan Feoli lebih lanjut menunjukkan bahwa kadar antioksidan katalase jumlahnya menurun pada kondisi malnutrisi (7). Liu dan Chui membuktikan bahwa pemberian antioksidan mempunyai pengaruh dalam meningkatkan fungsi kognisi (8). Perbaikan nutrisi pada diet yang diberikan akan memberikan perbaikan pada status redox dari otak tikus yang mengalami malnutrisi. Peningkatan antioksidan enzimatik superoksid dismutase (SOD), menurunnya malonaldehid (MDA) sebagai produk degradasi lemak akibat reaksi lipoperoksidasi, dan oksidasi protein pada hippocampus tikus umur 21 hari dan 75 hari (9). Diet kurang protein yang diberikan kepada tikus mempunyai pengaruh negatif terhadap pembentukan sitoskeletal di sel-sel neuron hipokampus otak dan menghambat ekspresi proteinprotein yang mempunyai peran dalam proses memori visuo spatial (10). Proses memori yang terganggu mempunyai kaitan erat dengan prosesmemori visuo spatial (10). Proses memori yang terganggu mempunyai kaitan erat dengan proses degenerasi dalam otak pada daerah hipokampus yang disebut degenerasi neurofibriler (10). Lebih jauh lagi diketahui bahwa degenerasi jenis ini merupakan jenis degenerasi yang bertanggungjawab terhadap terjadinya gangguan memori ringan (mild cognitive impairment). Ansari membuktikan bahwa gangguan oksidasi pada otak mempunyai hubungan kuat terjadinya penyakit gangguan memori Alzheimer (11).

Salah satu tanaman yang akhir-akhir ini mulai populer dikembangkan potensinya sebagai sayuran alternatif untuk menanggulangi malnutrisi dibelahan dunia adalah
Moringa oleifera atau dikenal di Indonesia sebagai tanaman kelor. Beberapa LSM di luar negeri menggunakan tanaman kelor ini untuk mengatasi permasalahan gizi di beberapa negara-negara Afrika (12). Selain kandungan protein di dalamnya, diduga antioksidan yang terkandung didalam tanaman ini mempunyai efek dalam perbaikan malnutrisi. Ciliberto mengungkapkan bahwa penyebab gangguan malnutrisi tidak sekedar sebagai akibat gangguan intake asupan makanan yang adekuat seperti yang disangka banyak orang selama ini. Penelitiannya yang dilakukan di Malawi menyimpulkan bahwa rendahnya kadar antioksidan ikut bertanggungjawab dalam terjadinya malnutrisi (13). Dengan maraknya penggunaan tanaman kelor $M$. oleifera sebagai terapi suplemen untuk penanganan malnutrisi, akhir-akhir ini mulai banyak diteliti kandungan antioksidan yang terkandung di dalamnya. Ditemukannya sejumlah antioksidan quercetin dan kaempferol pada tumbuhan ini membuka peluang untuk penelitian potensi tumbuhan ini sebagai agen scavenger untuk menangkap radikal bebas peroksid dan superoksid. Kandungan antioxidan dari kelor pernah dilaporkan membawa perbaikan dalam mencegah stress oksidatif yang diakibatkan terapi tuberkulosis. Rachmi juga menunjukkan bahwa antioksidan dari tanaman ini memberikan efek scavenging terhadap oksidasi yang diakibatkan CCl4 terhadap sel-sel hati (14).

Riset-riset yang dikembangkan selama ini banyak terfokus pada kaitan M. oleifera sebagai terapi nutrisi telah banyak dilakukan, akan tetapi belum didapatkan penelitian yang mengkaji peran efek antioksidatif yang dikandung $M$. oleifera dalam memperbaiki fungsi memori, terutama pada tikus model kurang energi protein. Dalam penelitian ini, akan dikaji lebih dalam hubungan antara efek antioksidatif $M$. oleifera di daerah hipokampus otak dan pengaruhnya terhadap gambaran histopatologisnya untuk kemudian dilihat pengaruhnya terhadap fungsi memori tikus model kurang energi protein.

\section{METODE}

Penelitian ini merupakan suatu studi eksperimental dengan desain pola post-test only randomized control group in vivo. Rancangan penelitian yang digunakan adalah Rancangan Acak Lengkap (RAL). Subyek tikus putih Rattus novergicus strain Wistar. Dalam penelitian ini terdapat 5 kelompok yang terdiri dari kelompok perlakuan kontrol P0 (perlakuan diet karak nasi), P1 (perlakuan diet PARS), P2 (perlakuan diet malnutrisi + supplemen tepung daun kelor dosis $180 \mathrm{mg}$ ), P3 (perlakuan diet malnutrisi + supplement tepung daun kelor dosis $360 \mathrm{mg}$ ) dan P4 (kelompok perlakuan diet malnutrisi + suplemen tepung daun kelor dosis $720 \mathrm{mg}$ ). Masing-masing kelompok terdiri dari 4 pengulangan.

\section{Uji Memori Morris Watermaze}

Aparatus uji yang digunakan dalam uji memori ini adalah kolam renang mini terbuat dari polypropylene (diameter $158 \mathrm{~cm}$ dan tinggi $60 \mathrm{~cm}$ ) yang diisi air dengan suhu $21^{\circ} \mathrm{C}$, dan kedalaman air $37.5 \mathrm{~cm}$. Air dibuat keruh dengan menambahkan susu bubuk sebanyak 2000 cc. Sebuah platform setinggi $35 \mathrm{~cm}$, dengan keliling $14 \mathrm{~cm}$, diletakkan $2 \mathrm{~cm}$ dibawah permukaan air, dan bisa ditinggikan setinggi $0,5 \mathrm{~cm}$ diatas permukaan air. Pada saat percobaan, petanda-petanda sederhana seperti kartu gambar silang berwarna hitam, berukuran $10 \times 7 \times 2,5 \mathrm{~cm}$, diletakkan 25 $\mathrm{cm}$ di atas platform. Di luar kolam uji diletakkan petanda- 
petanda tambahan dan penguji tetap berdiri di posisi yang sama sampai seluruh pengujian dirampungkan (15).

\section{Pemeriksaan SOD Jaringan Otak}

Jaringan otak yang diambil adalah potongan coronal setebal $2 \mathrm{~mm}$ yang diambil dari pada titik $6 \mathrm{~mm}$ jarak linea interauralis. Setelah tikus dilakukan pembedahan, maka tengkorak tikus dibelah dari arah caudo rostral pada garis sutura sagitalis. Otak tikus dipotong pada bagian mesensefalon dan dilepaskan dari jaringan nervi craniales disekitarnya. Sampel seberat $200 \mathrm{mg}$ (otak), dihomogenasi dengan bufer fosfat sebanyak $2 \mathrm{cc}$, kemudian disentrifus $4000 \mathrm{rpm}$ dalam $4^{\circ} \mathrm{C}$ selama 10 menit. Diambil supernatan sampel 200ul atau serum 200uL ditambahkan EDTA $100 \mathrm{uL}$, xanthine 100uL, xanthine oxidase 100uL, bufer fosfat, dan diinkubasi dalam $37^{\circ} \mathrm{C}$ selama 30 menit. Selanjutnya disentrifus dan disaring, kemudian ditambahkan buffer fosfat hingga 3 cc. Sediaan siap diukur dengan spektrofotometer pada panjang gelombang $580 \mathrm{~nm}$. Penentuan kadar dilakukan dengan menggunakan kurva baku. Data dianalisis menggunakan one way ANOVA untuk melihat perbedaan status oksidatif SOD antar perlakuan. Uji korelasi Spearman digunakan untuk melihat hubungan dosis dan respon.

\section{HASIL}

Pada uji analisis pemberian serbuk daun kelor dosis 180 mg $(37,20 \pm 10,65)$ meningkatkan jumlah SOD dibanding kontrol malnutrisi $(14,37 \pm 7,48)$. Pemberian serbuk daun M. oleifera kadar $360 \mathrm{mg}$ meningkatkan kadar SOD paling tinggi $(78,10 \pm 2,96)$ dengan peningkatan bermakna $(p<0,001)$ dibanding dengan dosis $180 \mathrm{mg}(37,19 \pm 10,65)$ dan dengan dosis $720 \mathrm{mg}(67,77 \pm 3,85)$. Tidak didapatkan hubungan korelasi antara dosis dan respons terhadap kadar SOD $(r=-146, p=0,3)$.

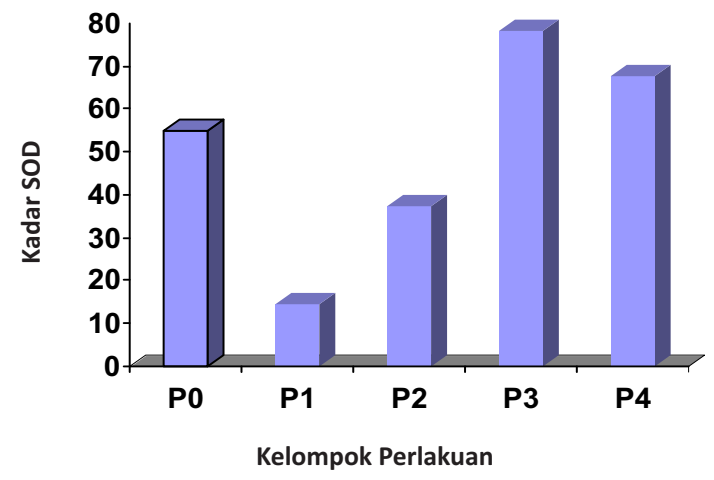

Gambar 1. Pengaruh pemberian kelor M.oleifera dalam meningkatkan aktivitas SOD hipokampus dalam \%.

Keterangan : P0 = perlakuan diet karak nasi; $\mathrm{P} 1=$ perlakuan diet PARS; $\mathrm{P} 2=$ Perlakuan diet malnutrisi + suplemen tepung daun kelor dosis 180 mg; P3= perlakuan diet malnutrisi + suplemen tepung daun kelor dosis 360 mg; $\mathrm{P} 4=$ kelompok perlakuan diet malnutrisi + suplemen tepung daun kelor dosis $720 \mathrm{mg}$

pemberian serbuk daun kelor dosis $180 \mathrm{mg}$ kelompok perlakuan P3 $(92,00 \pm 107,64885)$ meningkatkan memori dibanding kontrol malnutrisi (198,13 $\pm 124,71)$. Pemberian serbuk daun dosis $360 \mathrm{mg}(150,44 \pm 107,77)$ dan dosis $720 \mathrm{mg}(186,81 \pm 13)$ tidak meningkatkan fungsi memori secara bermakna $(p=0,24)$. Uji Spearman menunjukkan hubungan korelasi antara dosis $M$. oleifera dengan respons terhadap waktu laten.

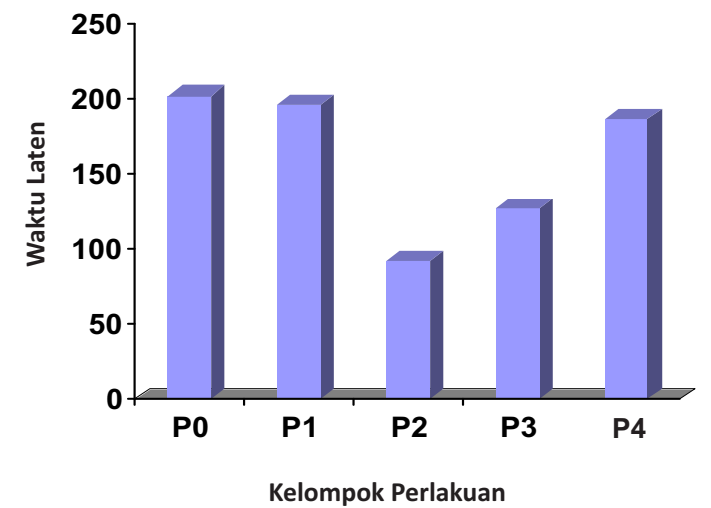

Gambar 2. Pengaruh pemberian kelor M. Oleifera dalam menurunkan waktu laten (ms) pada kelompok perlakuan

Keterangan $: \mathrm{PO}=$ perlakuan diet karak nasi; $\mathrm{P} 1=$ perlakuan $\operatorname{diet} \mathrm{PARS} ; \mathrm{P} 2=$ Perlakuan diet malnutrisi + suplemen tepung daun kelor dosis $180 \mathrm{mg}$; P3= perlakuan diet malnutrisi + suplemen tepung daun kelor dosis 360 $\mathrm{mg}$; $\mathrm{P} 4=$ kelompok perlakuan diet malnutrisi + suplemen tepung daun kelor dosis $720 \mathrm{mg}$

\section{DISKUSI}

Malnutrisi intranatal dan postnatal mempunyai efek negatif terhadap tumbuh kembang otak dengan dibuktikannya peningkatan produk degradasi lemak malonaldehid yang menunjukkan adanya proses oksidasi (8). Partadiredja membuktikan bahwa kondisi malnutrisi pada tikus akan menurunkan kadar antioksidan glutatione pada lobus prefrontalis jaringan otaknya (16). Feoli melaporkan bahwa tikus yang diberi perlakuan diet malnutrisi mempunyai kadar thiobarbutiric acid reactive substance yang lebih tinggi secara signifikan yang menunjukkan adanya proses peroksidasi lemak akibat stress oksidatif (7). Dengan perbaikan nutrisi pada diet yang diberikan akan memberikan perbaikan antioksidan enzimatik SOD pada hippocampus tikus umur 21 hari dan 75 hari.

Antioksidan mempunyai pengaruh dalam meningkatkan fungsi kognisi. Dagon membuktikan bahwa perbaikan pada status nutrisi akan memberikan perbaikan pada fungsi kognisi (17). Penelitian yang dilakukan oleh Chui membuktikan bahwa pemberian antioksidan mempunyai peran penting dalam memperbaiki proses kognisi. Terbukti bahwa pemberian tablet antioksidan dapat meningkatkan fungsi memori jangka pendek pada penderita diabetes melitus tipe 2 (8).

Dari hasil penelitian yang didapatkan, didapatkan bahwa pemberian tepung daun $M$. oleifera pada tikus dengan diet KEP mempunyai pengaruh yang bermakna dalam meningkatkan kadar SOD dalam jaringan otak tikus. Kandungan senyawa fenol daun M.oleifera diduga mempunyai aktivitas antioksidatif ini. Penelitian yang dilakukan oleh sebelumnya oleh Rachmi membuktikan bahwa ekstrak daun $M$. oleifera mengandung gugus fenol yang mempunyai efek protektif terhadap dari stress oksidatif (14). Sidharaju dan Becker melaporkan bahwasenyawa biokatif yang utama dari gugus fenol ini masih merupakan golongan flavonoid seperti quercetin dan kaempferol. Eksperimen yang dilakukan Bonatto menunjukkan tikus yang diberikan diet rendah protein kadar antioksidan katalase dan kadar SOD menurun pada cerebellum dari tikus (9). 
Kadar SOD pada korteks serebri tidak berbeda baik pada kelompok tikus malnutrisi maupun kelompok kontrol. Aktifitas katalase meningkat pada korteks tikus malnutrisi

Hasil penelitian membuktikan pengaruh daun M. oleifera dosis $180 \mathrm{mg}$ terhadap perbaikan memori dengan menggunakan metode Morris watermaze. Pemberian dosis yang lebih tinggi, $360 \mathrm{mg}$ dan $720 \mathrm{mg}$, tidak dapat memberikan hasil yang sama baik daripada dosis $180 \mathrm{mg}$. Kemungkinan hal ini dikarenakan efek antioksidatif dari daun M. oleifera yang terkandung didalamnya. Jejas oksidatif diduga ikut terlibat dalam proses kehilangan memori. Pemberian antioksidan diharapkan dapat memberikan perbaikan pada gangguan memori dalam hal ini disebabkan karena rendahnya intake yang menyebabkan tingginya jejas oksidatif. Salah satu penyebab jejas oksidatif adalah kurangnya intake gizi yang adekuat merupakan teori terbaru. Hal ini yang mendasari bahwa salah satu penyebab terganggunya gangguan memori dini adalah kekurangan nutrisi. Selain itu gangguan memori yang diakibatkan malnutrisi juga diiduga melibatkan gangguan micro environtment otak dalam hal ini hippocampus yang merupakan tempat

\section{DAFTAR PUSTAKA}

1. Arisman. Buku Ajar Ilmu Gizi. Jakarta: EGC; 2010.

2. Rizqiyah R. Pengaruh Pemberian Tepung Kelor dan Tepung Bekicot terhadap Jumlah Limfosit Tikus whistar dalam Kondui Kurang Energi Protein. [Skripsi]. Universitas Brawijaya, Malang. 2009.

3. Yakoob MY, Menezes EV, Soomro T, Haws RA, Darmstadt GL, and Bhutta ZA. Reducing Stillbirths: Behavioural and Nutritional Interventions Before and During Pregnancy. BioMed Central Pregnancy \& Childbirth. 2009; 9 Suppl 1: S3.

4. Hasanah S. Aktivitas Ekstrak Etil Asetat Daun Dewandaru (Eugenia uniflora L) Sebagai Agen Pengkhelat Logam Fe dan Penangkap Malonaldehid (MDA). [Skripsi]. Universitas Muhammadiyah, Surakarta. 2008.

5. Martinez Y, Diaz-Cintra S, Leon-Jacinto U, et al. Effects of Postnatal Malnutrition and Senescence on Learning, Long-term Memory, and Extinction in the Rat. Behavioural Brain Research. 2009; 203(1): 48-53.

6. Bonatto F, Polydoro M, Andrades ME, et al. Effects of Maternal Protein Malnutrition on Oxidative Markers in the Young Rat Cortex and Cerebellum. Neuroscience Letter. 2006 ; 406(3): 281-284.

7. Feoli $A M$, Siqueira IR, Almeida L, et al. Effects of Protein Malnutrition on Oxidative Status in Rat Brain. Nutrition. 2006; 22(2): 160-165.

8. Chui $\mathrm{MH}$ and Greenwood CE. Antioxidant Vitamins Reduce Acute Meal-induced Memory Deficits in Adults with Type 2 Diabetes. Nutrition Research. 2008; 28(7): 423-429.

9. Bonatto $\mathrm{F}$, Polydoro $\mathrm{M}$, Andrades ME, et al. Effect of Protein Malnutrition on Redox State of the Hippocampus of Rat. Brain Research. 2005; 1042(1): 17-22.

10. Illiandri O, Widjajanto E, dan Mintaroem K. Efek Pemberian Serbuk Daun Kelor (Moringa oleifera) terhadap Neuron penyimpanan memori baik memori pengenalan kembali yang bersifat asosiatif maupun pengenalan kembali yang bersifat tradisional. Hal ini dibuktikan dengan perusakan area hippokampus menimbulkan gejala-gejala gangguan memori. Formasi neurofibriler pada neuron ini merupakan formasi awal dari terjadinya bentukan protein yang bertanggungjawab terhadap gangguan memori. Illiandri melaporkan bahwa pada bentukan neurofibriller juga didapatkan pada tikus yang mendapatkan perlakuan diet rendah protein (10). Malnutrisi merupakan salah satu faktor yang mempengaruhi terbentuknya protein tau yang bertanggung jawab terhadap terjadinya penurunan fungsi memori pada penyakit Alzheimer (18).

Dari hasil penelitian dan pembahasannya, dapat disimpulkan pemberian tepung daun kelor varietas NTB mempunyai peran dalam meningkatkan kadar SOD pada jaringan hipokampus otak tikus dengan kondisi KEP dan pemberian tepung daun kelor varietas NTB mempunyai peran dalam perbaikan fungsi memori dengan menggunakan metode uji fungsi memori metode Morris watermaze pada tikus dengan diet KEP.

Neurofibriler pada Hipokampus Otak Tikus Model Kurang Energi Protein. Prosiding Pertemuan IImiah Nasional, Perhimpunan Ahli Anatomi Indonesia. Jakarta, 27-28 November 2010.

11. Ansari MA and Scheff SW. Oxidative Stress in the Progression of Alzheimer Disease in the Frontal Cortex. J Neuropathology and Experimental Neurology. 2010; 69(2): 155-167.

12. Fahey JW. Moringa oleifera: A Review of the Medical Evidence for Its Nutritional, Therapeutic, and Prophylactic Properties. Part 1. Trees for Life Journal; 2005.

13. Ciliberto $\mathrm{H}$, Ciliberto $\mathrm{M}$, Briend $\mathrm{A}$, Ashorn $\mathrm{P}$, Bier $\mathrm{D}$, and Manary M. Antioxidant Supplementation for The Prevention of Kwashiorkor in Malawian Children: Randomised, Double Blind, Placebo Controlled Trial. British Medical Journal. 2005; 330: 1109.

14. Rachmi E. Pengaruh Antioksidan dari Ekstrak Daun Moringa Oleifera terhadap Hepatotoksisitas CCL4. [Tesis]. Universitas Brawijaya, Malang. 2004.

15. Terry AV. Spatial Navigation (Water Maze) Tasks. Dalam: Buccafusco JJ, Simon S, Nicolelis M. Methods of Behavior Analysis in Neuroscience. Taylor \& Francis Group, LLC; 2009.

16. Partadiredja G, Worrall S, and Bedi KS. Early Life Undernutrition Alters the Level of Reduced Glutathione but not the Activity Levels of Reactive Oxygen Species Enzymes or Lipid Peroxidation in the Mouse Forebrain. Brain Research. 2009; 1285: 22-29.

17. Dagon Y, Avraham Y, Magen I, Gertler A, Ben-Hur T, and Berry EM. Nutritional Status, Cognition, and Survival: A New Role for Leptin and AMP Kinase. The Journal of Biological Chemistry. 2005; 280(51): 42142-42148.

18. Broadbent NJ, Gaskin S, Squire LR, and Clark RE. Object Recognition Memory and the Rodent Hippocampus. Learning \& Memory. 2009; 17(1): 5-11. 